\title{
Effects of Holothuroid Ichtyotoxic Saponins on the Gills of Free-Living Fishes and Symbiotic Pearlfishes
}

\author{
IGOR EECKHAUT $^{1 *}$, GUILLAUME CAULIER ${ }^{1}$, LOLA BRASSEUR $^{1}$, PATRICK FLAMMANG $^{1}$, \\ PASCAL GERBAUX ${ }^{2}$, AND ERIC PARMENTIER ${ }^{3 *}$ \\ ${ }^{1}$ Biology of Marine Organisms and Biomimetics, University of Mons, B-7000 Mons, Belgium; ${ }^{2}$ Synthesis \\ and Organic Mass Spectrometry, University of Mons, B-7000 Mons, Belgium; and ${ }^{3}$ Laboratory of \\ Morphology, University of Liège, B6 Sart Tilman, B-4000 Liège, Belgium
}

\begin{abstract}
Several carapid fishes, known as pearlfishes, are endosymbiotic in holothuroids and asteroids. These echinoderms contain a strong concentration of saponins that are efficient membranolytic repellents to predators. We compared the effects of exposure to saponins from the sea cucumber body wall and from the Cuvierian tubules on the behavior and gill ultrastructure of pearlfishes and free-living fishes. Saponins were extracted from the body wall of two holothuroids, the Mediterranean Holothuria forskali and the tropical Bohadschia atra, and from the water surrounding the Cuvierian tubules of $B$. atra. Five species of carapids that live in symbiosis with holothuroids and seven species of free-living fishes were exposed to these extracts. The free-living fishes exhibited a stress response and died about 45 times faster than pearlfishes when exposed to the same quantity of saponins. Cuvierian tubules and saponins extracted from the body wall were lethal to the free-living fishes, whereas the carapids were much less sensitive. The carapids did not exhibit a stress response.The high toxicity shown by Cuvierian tubules was not explained by the nature of the saponins that were identified by mass spectrometry, but it is likely due to the higher concentration of saponins in the tubules. Histology and scanning and transmission electron microscopy of the gills of the free-living fishes and pearlfishes showed that saponins act at the level of the secondary lamellae where they induce the detachment of the epithelia, create edema at the level of the epithelia, and induce pores in the epithelial cells that lead to their destruction and the invasion of inner cells (pillar cells and red
\end{abstract}

Received 16 July 2014; accepted 22 April 2015.

* To whom correspondence should be addressed. E-mail: igor.eeckhaut@ umons.ac.be or e.parmentier@ulg.ac.be

Abbreviations: OM, opercular movements. blood cells). This sequence of events happens $5 \mathrm{~min}$ after saponin exposure in free-living fishes and after $1 \mathrm{~h}$ in carapids.

\section{Introduction}

Coral reefs form complex marine ecosystems where thousands of animal associations occur, such as those involving invertebrates and fishes. Among them, the anemone/clownfish symbiosis is probably the best known (e.g., Mebs, 1994; Elliott and Mariscal, 1997; Cleveland et al., 2011), but another extraordinary example, though less known, is the symbiosis between carapid fishes (Ophidiiformes) and various invertebrates. Although several species are free-living, those belonging to the genera Carapus, Encheliophis, and Onuxodon are able to enter and live inside different invertebrates, especially echinoderms such as holothuroids and asteroids. These remarkable associations account for the notoriety of the group (Trott, 1981; Markle and Olney, 1990). Species belonging to the genera Carapus and Onuxodon are commensals, whereas Encheliophis species are regarded as parasites (Parmentier and Das, 2004; Parmentier and Michel, 2013). Parasitic species reside inside their hosts and eat their internal tissues (gonads, digestive glands); commensals use their hosts as shelters and feed outside them (Parmentier and Vandewalle, 2003; Parmentier and Das, 2004).

It is well known that holothuroid tissues contain a high quantity of saponins (Nigrelli, 1952; Van Dyck et al., 2009, 2010), secondary metabolites that act as a predator deterrent. They are abundant in the body wall and are also 
particularly concentrated in the Cuvierian tubules, a specialized defense system developed by some sea cucumber species of the family Holothuriidae (Matsuno and Iba, 1966; Elyakov et al., 1973). This organ, located in the posterior part of the animal, consists of multiple tubules that can be expelled out of the cloacum after stimulation (Hamel and Mercier, 2000; Flammang et al., 2002). Expelled tubules lengthen into sticky white threads that may entangle potential predators.

Saponins are an important class of natural products first discovered in higher plants, where they are widely distributed (for example in the families Dioscoreaceae, Araliaceae, Leguminosae, Cucurbitaceae) (Li et al., 2006). In these plants, saponins are found in different compartments such as the rhizome, the leaves, and the cortex (Guo et al., 2006). Owing to their wide variety of biological and pharmacological activities, vegetal saponins are part of the most efficient compounds in popular Chinese medicine (Guo et al., 2006). Nigrelli (1952) and Yamanouchi (1955) were the first to investigate the saponins of sea cucumbers (in Actinopyga agassizi and Holothuria leucospilota, respectively). Since these contributions, saponins have been isolated from numerous species of Aspidochirotida and Dendrochirotida and also from sea stars (Mackie and Turner, 1970; Kitagawa and Kobayashi, 1977; Demeyer et al., 2014). More recently, they have also been noted in sponges (Thompson et al., 1985; Kubanek et al., 2000) and in chrysomelid beetles (Plasman et al., 2000a, b). Saponins have been reported to possess a wide range of biological activities including hemolytic, antitumoral, anti-inflammatory, antifungal, anti-bacterial, cytostatic, and ichthyotoxic properties (Kalinin et al., 1996a, b, 2008; Prokofeva et al., 2003; Bordbar et al., 2011). Many of these activities are the result of their cytotoxic action - that is, their capacity to induce disturbances, up to lysis, in cellular membranes (Kalinin et al., 1996a). It has been established that a majority of the saponin activities are the consequence of their interaction with cell membrane $\Delta^{5}$ sterols, especially cholesterol (Popov et al., 1983; Stonik et al., 1999). This interaction induces significant changes in the physicochemical properties of cell membranes, such as variations in their stability, microviscosity, and permeability. Saponins form complexes with membrane sterols, leading to cell disruption by the formation of pores. Due to this irreversible interaction, the selective permeability of cell membranes is impaired and cell compounds are transferred into the extracellular matrix, ultimately resulting in cell death (Segal and Schlösser, 1975). The toxic activity of saponins on organisms is well known. Yamanouchi (1955) found that holothuroid saponins kill marine and freshwater fishes, and also earthworms. He observed that freshwater fishes are more resistant to saponins than are marine fishes, and he suggested that it is because the gills of the latter are less permeable. The people of Guam traditionally used holothuroids to poison coral fishes: they cut the holothuroids and squeezed out their contents to render the fishes weak and less active (Bakus, 1973).
Pearlfishes are less sensitive to the ichtyotoxic holothuroid saponins than are other fishes (Parmentier and Vandewalle, 2005). Parmentier and Vandewalle (2005) found that the time required for carapids to die when exposed to holothuroid saponins is 2 to 16 times longer than for other fishes and suggested that the resistance of pearlfishes to holothuroid toxins may be related to specializations of the gills. Mucus coating may also assist the fish in resisting the sticky substances emitted by the Cuvierian tubules (Trott, 1970). Here, we compare the effects of exposure to Cuvierian tubules and to saponin extracts on the ultrastructure of the gills of free-living fish species and pearlfishes (the gills are assumed to be the fish organs most affected by membranolytic saponins). We also compare the survival times and motion behavior of these fishes when they are exposed to the various saponins, and we use mass spectrometry to characterize the nature of the saponin cocktails that were used.

\section{Materials and Methods}

\section{Samples}

Twelve fish species, including 5 carapids and 7 species of free-living fishes, were used in the analyses. The pearlfishes Carapus homei (Richardson, 1846), C. mourlani (Petit, 1934), and Encheliophis gracilis (Bleeker 1856) were collected from the Great Reef of Toliara (Madagascar) in January and February 2008 and 2009; C. boraborensis (Kaup, 1856) and other individuals of $C$. homei from the Opunohu Bay of Moorea (French Polynesia) in October 2008; and C. acus (Brünnich, 1768) from the Bay of Calvi (Corsica) in June 2008 and 2009. The free-living fishes were used as a control to assess potential specialization of the pearlfishes. These species included Amphiprion akallopisos Bleeker 1853 (Pomacentridae), Dascyllus aruanus (Linnaeus, 1853) (Pomacentridae), from Toliara; D. flavicaudus Randall and Allen, 1977 (Pomacentridae), D. trimaculatus (Rüppell, 1829) (Pomacentridae), Neoniphon sammara (Forsskaal,1775) (Holocentridae), and other individuals of Dascyllus aruanus from Moorea (French Polynesia); Symphodus ocellatus (Linnaeus, 1758) (Labridae) and Coris julis (Linnaeus, 1758) (Labridae) from Calvi (Corsica).

The carapids were collected by scuba diving (3-15-m depth), along with their holothuroid hosts (Bohadschia argus Jaeger, 1833, Bohadschia atra Massin, Rasolofonirina, Conand \& Samyn, 1999, Thelenota ananas (Jaeger, 1833), or Holothuria forskali Delle Chiaje 1823). The other species were collected with hand nets from sea anemones (Amphiprion akallopisos) or coral reef habitat. The animals were then kept in tanks of 201 at $27{ }^{\circ} \mathrm{C}$, with running seawater, for 2 days before being exposed to saponins or the presence of Cuvierian tubules. At the end of each test, some fishes were placed in the freezer to anesthetize and were then euthanized. Samples of their gills were taken 
Table 1

Morphological data on fishes and fish gills

\begin{tabular}{|c|c|c|c|c|c|}
\hline \multirow[b]{2}{*}{ Species } & \multirow[b]{2}{*}{ Collection Site } & \multirow[b]{2}{*}{ Length $(\mathrm{cm})$} & \multirow[b]{2}{*}{ Weight $(\mathrm{g})$} & \multicolumn{2}{|c|}{ Opercular Rhythm ( $\boldsymbol{n} / \mathrm{min})$} \\
\hline & & & & Normal & Exposed \\
\hline \multicolumn{6}{|l|}{ CARAPIDAE } \\
\hline Carapus acus & Calvi & $12.68 \pm 4.04$ & $4.98 \pm 0.90$ & $21.49 \pm 7.19$ & $24.27 \pm 6.63$ \\
\hline Carapus boraborensis & Moorea & $17.60 \pm 5.50$ & $9.22 \pm 7.08$ & $22.92 \pm 3.55$ & $11.42 \pm 7.28$ \\
\hline Carapus homei & Moorea & $13.26 \pm 1.14$ & $3.38 \pm 1.38$ & $48.91 \pm 6.98$ & $48.27 \pm 13.48$ \\
\hline Carapus mourlani & Toliara & $7.72 \pm 1.82$ & $1.94 \pm 0.91$ & $63.48 \pm 22.42$ & $29.96 \pm 26.58$ \\
\hline Encheliophis gracilis & Toliara & $21.07 \pm 2.39$ & $8.30 \pm 2.83$ & $69.87 \pm 6.78$ & $75.08 \pm 7.77$ \\
\hline \multicolumn{6}{|l|}{ CONTROL FISHES } \\
\hline Amphiprion akallopisos & Toliara & $7.97 \pm 1.88$ & $16.01 \pm 12.09$ & $182.96 \pm 24.01$ & $212.56 \pm 17.59$ \\
\hline Dascyllus aruanus & Moorea & $4.70 \pm 0.95$ & $4.23 \pm 4.31$ & $167.07 \pm 49.25$ & $191.46 \pm 33.40$ \\
\hline Dascyllus flavicaudus & Moorea & $4.60 \pm 1.39$ & $2.70 \pm 2.60$ & $174.08 \pm 27.39$ & $188.78 \pm 27.67$ \\
\hline Dascyllus trimaculatus & Moorea & $4.42 \pm 2.02$ & $2.83 \pm 5.22$ & $166.89 \pm 38.98$ & $196.78 \pm 30.02$ \\
\hline Neoniphon sammara & Toliara & $6.00 \pm 0.22$ & $3.11 \pm 0.38$ & $184.06 \pm 26.87$ & $195.56 \pm 18.38$ \\
\hline Coris julis & Calvi & $9.12 \pm 0.35$ & $13.64 \pm 8.53$ & $150.10 \pm 7.10$ & $188.02 \pm 10.7$ \\
\hline Symphodus ocellatus & Calvi & $5.07 \pm 0.36$ & $2.96 \pm 0.82$ & $146.00 \pm 12.4$ & $194.04 \pm 8.9$ \\
\hline
\end{tabular}

Opercular rhythms were obtained when fishes were exposed to $200 \mu \mathrm{g} / 1$ of saponins (extracted from Bohadschia atra or Holothuria forskali; see Materials and Methods) for $1 \mathrm{~h}$.

and fixed with Bouin's fluid or 3\% glutaraldehyde solution in cacodylate buffer for histology and scanning and transmission electron microscopy. Animals used in our experiments were maintained and treated in compliance with the guideline specified by the Belgian Ministry of Trade and Agriculture.

\section{Saponin extraction and identification}

Saponins of Bohadschia atra (from Toliara, Madagascar) and Holothuria forskali (from Calvi, Corsica) were used during the experiments. These species were collected at a depth of 20 to $40 \mathrm{~m}$ by scuba diving. Once in the laboratory, the holothurians were dissected and a piece of body wall was placed in $70 \%$ ethanol and stored at $-20{ }^{\circ} \mathrm{C}$ until extraction. Extracts were prepared as detailed in Van Dyck et al. (2009) and Caulier et al. (2013a, b). Basically, the purification consists in liquidliquid extractions with different organic solvents (hexane, dichloromethane, chloroform, isobutanol) and a solid phase chromatography (Xad 4 Amberlite). Some extracts were analyzed with mass spectrometry, and others were used in experiments to test the resistance of fishes to saponins. Cuvierian tubules of B. atra (from 4.7 to $37.3 \mathrm{~g}$ ) were removed from dissected individuals and placed in 1 liter of seawater for $1 \mathrm{~h}$. The saponin cocktails extracted from the holothuroid body wall and from the water conditioned by the Cuvierian tubules of $B$. atra were identified to determine similarities or differences that could help to explain the various effects observed. Mass spectrometry (Waters QToF Premier mass spectrometer) was performed in the positive ion mode, using the MALDI or the Electrospray ionization (ESI) sources (see also Van Dyck et al., 2009; Caulier et al., 2013a, b).

\section{Behavioral responses of fishes to saponin extract exposure}

The behavioral responses of 12 species of fishes $(5$ specimens for each) to saponin extracts was investigated (see Table 1). These fishes were exposed to saponins from the body wall of Bohadschia atra (for the tropical fish species) or Holothuria forskali (for the Mediterranean fish species). The final saponin concentration used in the 1-liter aerated aquaria was $200 \mu \mathrm{g} / \mathrm{ml}$, quantification being obtained through the weighing of the dried extract. The chosen concentration corresponds to the range of saponin concentration previously measured in the water conditioned by $H$. forskali (290 $\mu \mathrm{g} / \mathrm{l}$; Van Dyck et al., 2011) and by Bohadschia vitiensis (250 $\mu \mathrm{g} / \mathrm{l}$; Eeckhaut, unpubl. data). The motion behavior of fishes was observed for $2 \mathrm{~h}$, and the respiration rate, estimated by the frequency of opercular movements (abbreviated to OM hereafter), was recorded with a handheld counter after $1 \mathrm{~h}$ of exposure. Fishes were first left in the aquarium for $15 \mathrm{~min}$ before the beginning of the test to allow them to get used to the new container, and saponins were then introduced.

\section{Behavioral responses of fishes to Cuvierian tubules exposure}

For nine tropical species (see Table 2), exposure to $\mathrm{Cu}$ vierian tubules was tested. Each replicate $(n=3)$ consisted of placing one specimen of Carapus (three tested species) or 
one of Encheliophis (one tested species) with one freeliving fish (five tested species) in a 2.5-1 tank with Cuvierian tubules (from 4.7 to $37.3 \mathrm{~g}$ ). Pearlfishes were tested with free-living fishes so as to expose them to the same tubule quantity and the same experimental conditions. The tubules used for the experiment were either directly expelled by the sea cucumber $B$. atra or removed from individuals after dissection. The times to mortality of fishes were recorded and their weights were taken at the end of the experiments.

\section{Statistics}

Nonparametric Mann-Whitney $U$-tests were performed (Statistica 7.0) to compare the averages of opercular movements between fish when exposed to saponin extracts. Comparisons were made between (i) each species of fish, (ii) free-living fishes and carapids, and (iii) Mediterranean and tropical species. The same tests were also applied to compare the average survival times between fishes exposed to Cuvierian tubules. Statistical significance was set to $5 \%$.

\section{Morphological analyses of the gills}

The gill morphology of the five species of carapids $(C$. homei, C. acus, C. mourlani, E. gracilis, and A. akallopisos) was examined with light (3 individuals) or electron microscopy (1 individual) before and after a 5-min exposure to saponin extract (free-living fishes) or $1 \mathrm{~h}$ (carapids) to Cuvierian tubules. The surface of the gills for the five species was compared with scanning electron microscopy; the histology in $C$. acus and A. akallopisos was compared, and the ultrastructure of the secondary lamellae of $C$. mourlani, E. gracilis, and A. akallopisos was observed with transmission electron microscopy after treatment.
Light microscopy. The samples were fixed in Bouin's fluid (with acetic acid) for $8 \mathrm{~h}$ and decalcified overnight in a $1: 1$ mixture of a $2 \%$ ascorbic acid solution and $\mathrm{NaCl} 0.3$ mol $1^{-1}$ at $4{ }^{\circ} \mathrm{C}$ (Dietrich and Fontaine, 1975). The samples were then dehydrated through a graded series of ethanol (70\%, 90\%, and 100\%), embedded in Paraplast, and cut into $7 \mu \mathrm{m}$ thick sections that were stained with a Masson trichrome (Ganter and Jollès, 1969-1970). The images were captured with an Olympus photomicroscope connected to a computer with the ImageJ, ver. 1.48, program.

Scanning electron microscopy (SEM). The samples were fixed in Bouin's fluid (without acetic acid) for $8 \mathrm{~h}$, dehydrated with a graded series of ethanol $(70 \%, 90 \%$, and $100 \%$ ) and critical-point dried. They were then mounted on aluminum stubs, coated with gold in a sputter-coater, and observed with a JEOL JSM-6100 scanning electron microscope.

Transmission electron microscopy (TEM). The samples were fixed in a $3 \%$ glutaraldehyde solution in $0.1 \mathrm{~mol} \mathrm{l}^{-1}$ cacodylate buffer ( $\mathrm{pH} 7.8$ ) for 3 to $24 \mathrm{~h}$ at $4{ }^{\circ} \mathrm{C}$. They were washed in the buffer before post-fixation in a $1 \%$ osmium tetroxide solution in the same buffer at $4{ }^{\circ} \mathrm{C}$ for $1 \mathrm{~h}$. Pieces were then decalcified for 1 week in a mixture of a $2 \%$ ascorbic acid solution and $\mathrm{NaCl} 0.3 \mathrm{~mol} \mathrm{l}^{-1}$ at 4 ${ }^{\circ} \mathrm{C}$. Decalcified samples were dehydrated through a graded series of ethanol $(70 \%, 90 \%, 100 \%)$, transferred into Spuur's resin at room temperature for $24 \mathrm{~h}$ followed by another $24 \mathrm{~h}$ at $60{ }^{\circ} \mathrm{C}$, and cut with a Leica ultracut UCT ultramicrotome. Sections were stained with lead citrate and uranyl acetate and observed with a Zeiss LEO 906E electron microscope.

Table 2

Average time to mortality of the fishes (controls and carapids; $\mathrm{n}=5$ ) when exposed to Cuvierian tubules from Bohadschia argus (for French Polynesian fishes) and B. atra (for Malgachian fishes)

\begin{tabular}{|c|c|c|c|c|c|c|c|c|c|c|c|c|}
\hline \multirow[b]{2}{*}{ Species } & \multicolumn{4}{|c|}{ Time to Mortality per Individual } & \multicolumn{4}{|c|}{$\begin{array}{l}\text { Time to Mortality/Weight of } \\
\text { Individual }\end{array}$} & \multicolumn{4}{|c|}{$\begin{array}{l}\text { Time to Mortality/Weight of } \\
\text { Individual/Weight Tubules }\end{array}$} \\
\hline & Time (min) & SD & MIN & MAX & Time $(\min )$ & $\mathrm{SD}$ & MIN & MAX & Time (min) & SD & MIN & MAX \\
\hline Amphiprion akallopisos & 7 & 1.7 & 5 & 8 & 0.8 & 0.6 & 0.3 & 1.5 & 0.03 & 0.11 & 0.02 & 0.04 \\
\hline Dascyllus aruanus & 4.7 & 0.6 & 4 & 5 & 3.1 & 1.6 & 1.7 & 4.8 & 0.58 & 0.45 & 0.14 & 1.04 \\
\hline Dascyllus flavicaudus & 5.2 & 1.3 & 4 & 6.5 & 3.1 & 3.1 & 0.8 & 6.6 & 0.61 & 0.7 & 0.04 & 1.4 \\
\hline Dascyllus trimaculatus & 5.5 & 1.8 & 4 & 7.5 & 0.4 & 0.1 & 0.3 & 0.6 & 0.05 & 0.03 & 0.02 & 0.08 \\
\hline Neoniphon sammara & 4 & 0.9 & 3 & 4.9 & 1.8 & 0.8 & 0.9 & 2.6 & 0.24 & 0.27 & 0.08 & 0.55 \\
\hline Carapus boraborensis & 280.7 & 127 & 154 & 392 & 43.2 & 30.4 & 10.9 & 80 & 6.53 & 7.33 & 0.54 & 17.02 \\
\hline Carapus homei & 226.2 & 105.8 & 124 & 323 & 82.7 & 25.3 & 47.1 & 103.5 & 12.29 & 10.54 & 2.32 & 22.03 \\
\hline Carapus mourlani & 155 & 52.2 & 120 & 215 & 64.9 & 21.3 & 52.4 & 89.6 & 3.3 & 2.9 & 1.4 & 6.64 \\
\hline Encheliophis gracilis & 282.2 & 138.4 & 193 & 488 & 51.7 & 43.6 & 24 & 116.8 & 7.23 & 11.74 & 0.85 & 24.84 \\
\hline
\end{tabular}

Takes into account (i) the individual, (ii) the weight of individuals, and (iii) the weight of individuals + the weight of Cuvierian tubules. 


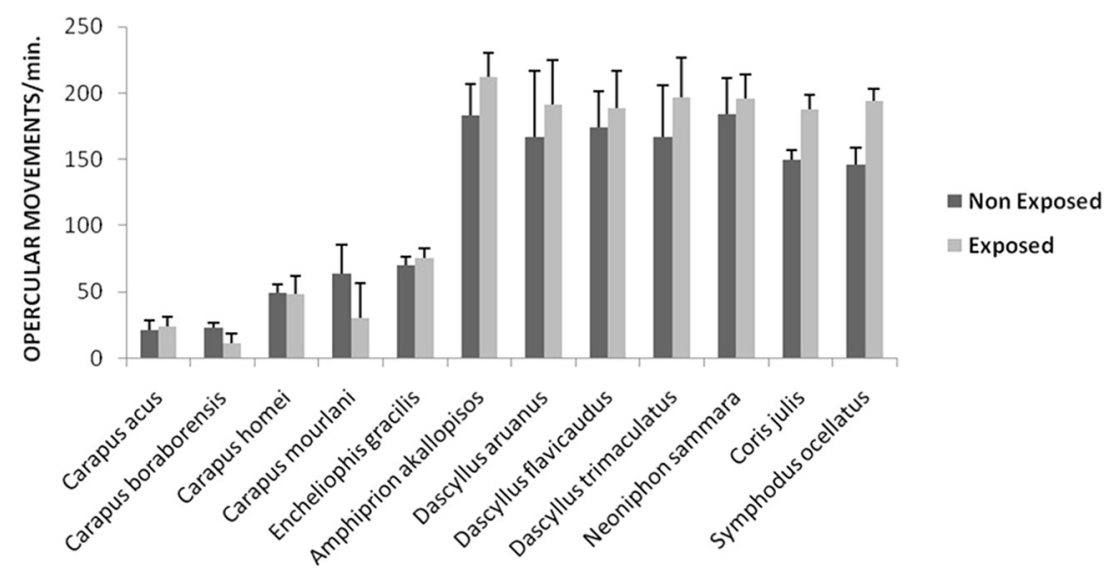

Figure 1. The number of opercular movements/minute in carapids and free-living fishes $(n=5$ for each species), exposed and nonexposed to saponins from holothuroids. Error bars correspond to standard deviation.

\section{Results}

\section{Behavior of free-living fishes and pearlfishes to saponin} exposure

Effect of saponin extract exposure. The recorded normal (i.e., non-exposed to saponins) opercular frequencies of free-living fishes varied between 146 and $184 \mathrm{mov} / \mathrm{min}$ (Table 1). There was no significant difference between the normal opercular frequencies of Polynesian and Malagasy fishes $(P>0.05)$, but there was between the tropical and Mediterranean fishes $(P<$ 0.05). When exposed to saponins, the opercular movements $(\mathrm{OM})$ of free-living fishes increased up to $200 \%$ during the first 10 to $15 \mathrm{~min}$ and then dropped to between $105 \%$ and $133 \%$ until the fishes died (Table 1). During the first $15 \mathrm{~min}$, the fishes showed a strong reaction in which they swam vigorously and randomly around the aquarium. After this first phase, the

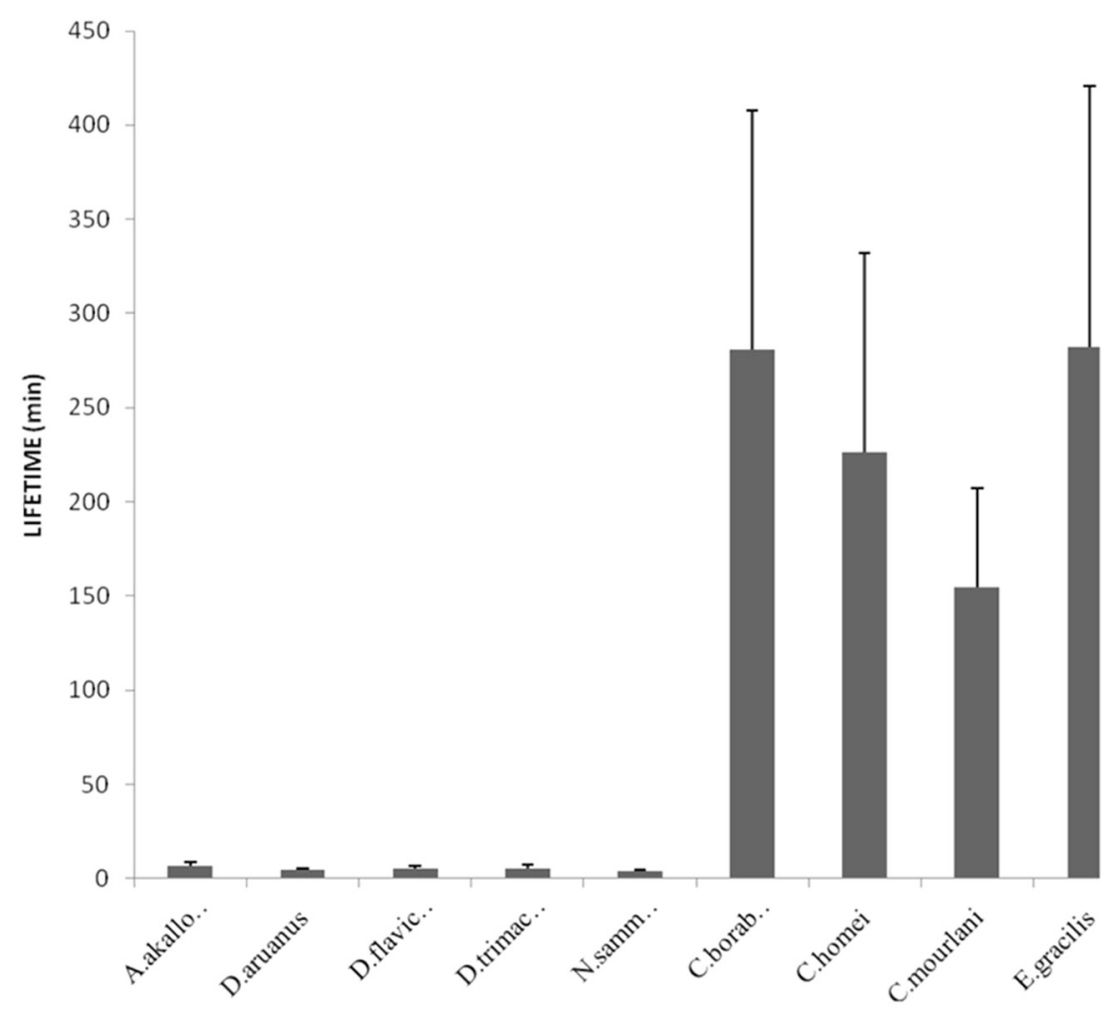

Figure 2. The time to mortality (minutes) of carapids and free-living fishes $(n=3)$ exposed to saponins of expelled Cuvierian tubules from holothuroids. Error bars correspond to standard deviation. 


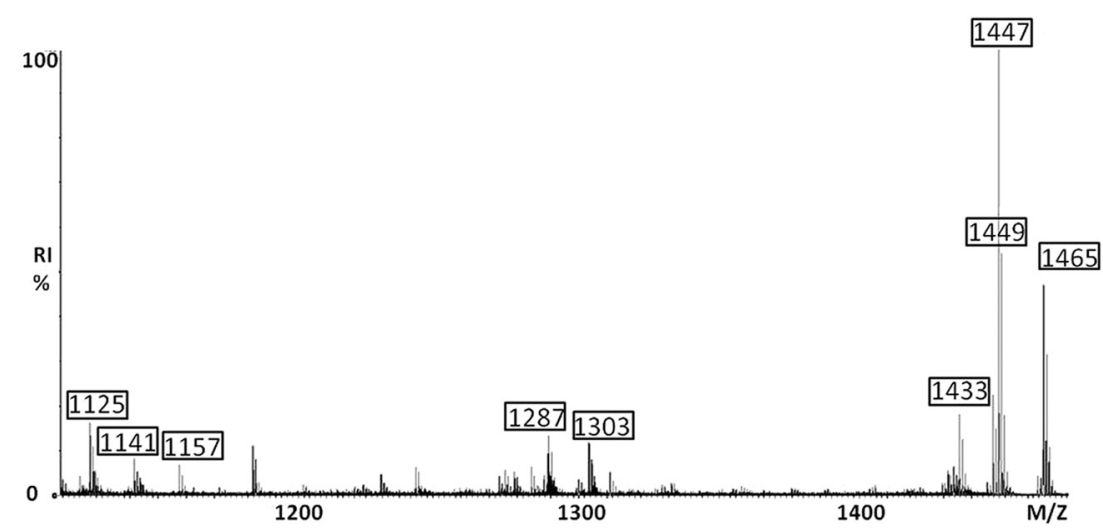

Figure 3. Full-scan $(+)$ MALDI-ToF mass spectrum analysis of the total saponin mixture extracted from the body wall of Bohadschia atra. Saponin signals are highlighted by boxed $m / z$ ions $\left[\mathrm{M}+\mathrm{Na}^{+}\right]$. The $y$ axis corresponds to the relative intensity.

free-living fish species became quiescent and then died within $2 \mathrm{~h}$ of exposure. Therefore, the first sign of saponin toxicity on free-living fishes was an increase in the frequency of $\mathrm{OM}$ (Table 1; Fig. 1). However, this increase was statistically significant only in Coris julis and Symphodus ocellatus $(P<$ $0.05)$.

The opercular frequencies of the carapids were much lower than those recorded for free-living fishes (21 to 70 $\mathrm{OM} / \mathrm{min}$ ) with the lowest in Carapus acus and the highest in Encheliophis gracilis (Table 1). OM of exposed carapids remained similar $(P>0.05)$ except in Carapus mourlani and Carapus boraborensis, where a decrease in the frequency of OM was observed (Table 1; Fig. 1). The decrease was very obvious in exposed $C$. mourlani, with the individuals totally stopping OM for several minutes.

Effects of Cuvierian tubules exposure. The observed effects were similar to those obtained with body wall extracts (i.e., the increase in $\mathrm{OM}$ in the free-living fishes was not observed in carapids), and the free-living fishes were affected much faster, all dying within 10 min of exposure to Cuvierian tubules. Death occurred even more quickly when the fish became entangled in the tubules $(210 \mathrm{~s}$. on average). In contrast, the carapids swam freely across Cuvierian tubules without being entangled in them. However, even though they were more resistant than freeliving fishes, they also died after a minimum of $2.5 \mathrm{~h}$. The average times to death of all tested fishes are summarized in Table 2 and illustrated in Figure 2. Table 2 shows (i) the average time to death of individuals (free-living and carapid) and the average lifetimes when these values were normalized by taking into account (ii) the weight of the individuals and (iii) the weight of the individuals and the weight of the Cuvierian tubules. In the three cases, the carapids were clearly much more resistant than the other fishes to the toxins expelled by Cuvierian tubules. The free-living fish Neoniphon sammara, which died on average 4 min after exposure, was the least resistant, while the most resistant was $E$. gracilis, which died after $282 \mathrm{~min}$. Taking into account the

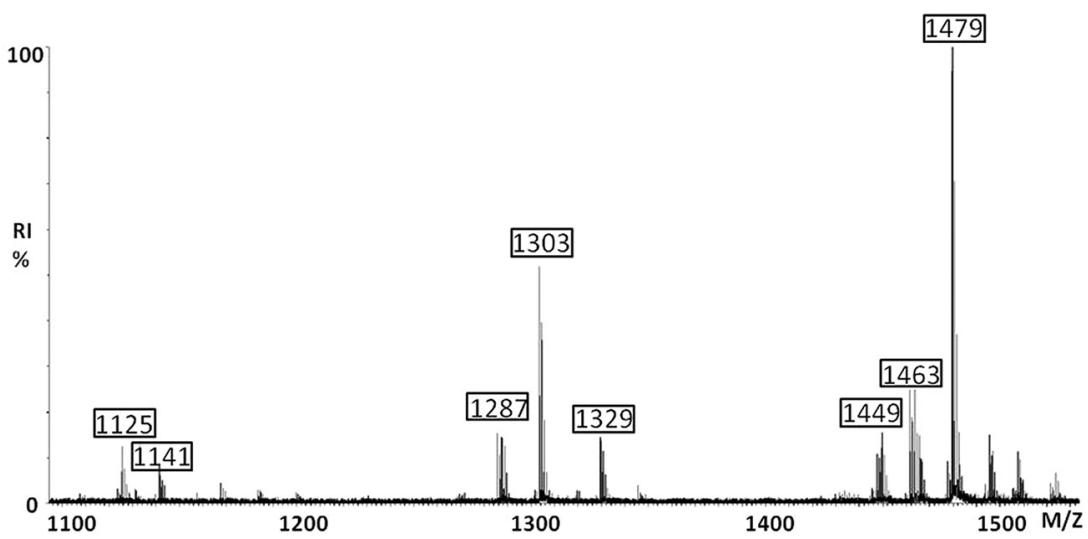

Figure 4. Full-scan (+) MALDI-ToF mass spectrum analysis of the total saponin mixture extracted from the water sample with the Cuvierian tubules of Bohadschia atra. Saponin signals are highlighted by boxed $\mathrm{m} / \mathrm{z}$ ions $\left[\mathrm{M}+\mathrm{Na}^{+}\right]$. The $y$ axis corresponds to the relative intensity. 

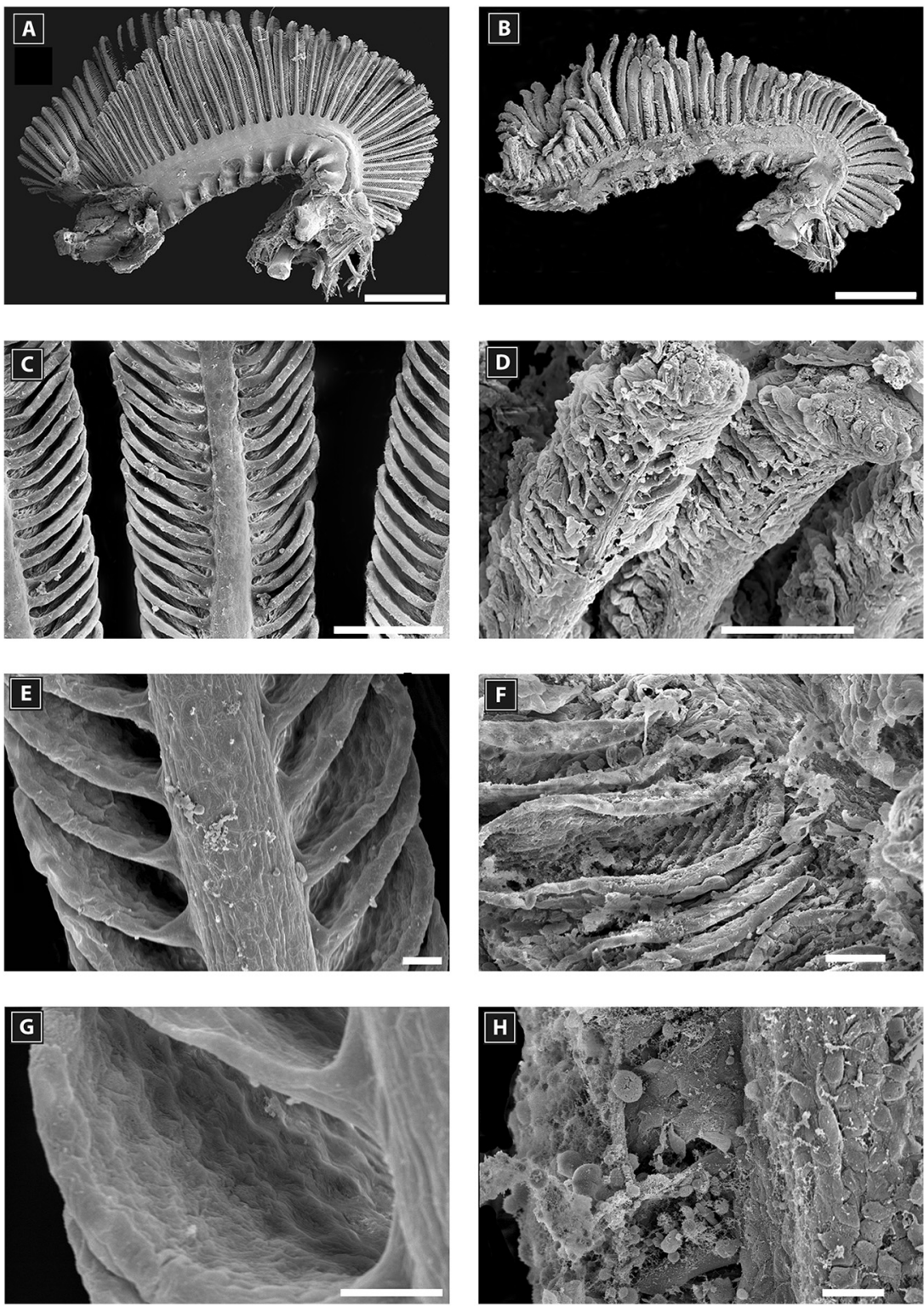

Figure 5. Scanning electron microscopy of a second gill arch of Amphiprion akallopisos unexposed to holothurian saponins in A, C, E, G and exposed to holothurian saponins in B, D, F, H. (A) and (B) general views of the second gill arch; (C) and (D) views of the primary lamellae; (E) and (F) views of the secondary lamellae; $(\mathrm{G})$ and $(\mathrm{H})$ details of a secondary lamella. Scale bar is $1 \mathrm{~mm}$ in A and B; $100 \mu \mathrm{m}$ in C, D; $20 \mu \mathrm{m}$ in E and F; $10 \mu \mathrm{m}$ in G and $\mathrm{H}$.

weight of individuals and the weight of Cuvierian tubules, Carapus homei appeared to be the most resistant fish. On average, the free-living fishes died 45 times faster than the carapids. There was no significant difference between saponin resistance among free-living species $(P>0.05)$, but there was between carapid species $(P<0.05)$. C. mourlani was the most sensitive, while the other three, $C$. homei, $C$. boraborensis, and E. gracilis, were very resistant to the action of Cuvierian tubules. However, the time to death of the carapids varied greatly within species, as indicated by the standard deviations (Fig. 2). In all tests with all fishes, the fish secreted a lot of mucus from their bodies and gills.

\section{Identification of the saponin extracts}

The full-scan MALDI mass spectrum of the saponin extract obtained from the body wall of $B$. atra displays nine intense peaks that correspond to triterpene saponins. Other peaks either correspond to plastic polymers or matrix complexes. The nine ions were detected at $\mathrm{m} / \mathrm{z}\left[\mathrm{M}+\mathrm{Na}^{+}\right]$ $1125,1141,1157,1287,1303,1433,1447,1449$, and 1465 (Fig. 3). Further mass spectrometric analyses, on an ESI-HPLC spectrometer, showed different isomers corresponding to Holothurinoside C, Desholothurin A, Holothurinoside K1, Holothurinoside E, Holothurinoside A, Holothurinoside F, 

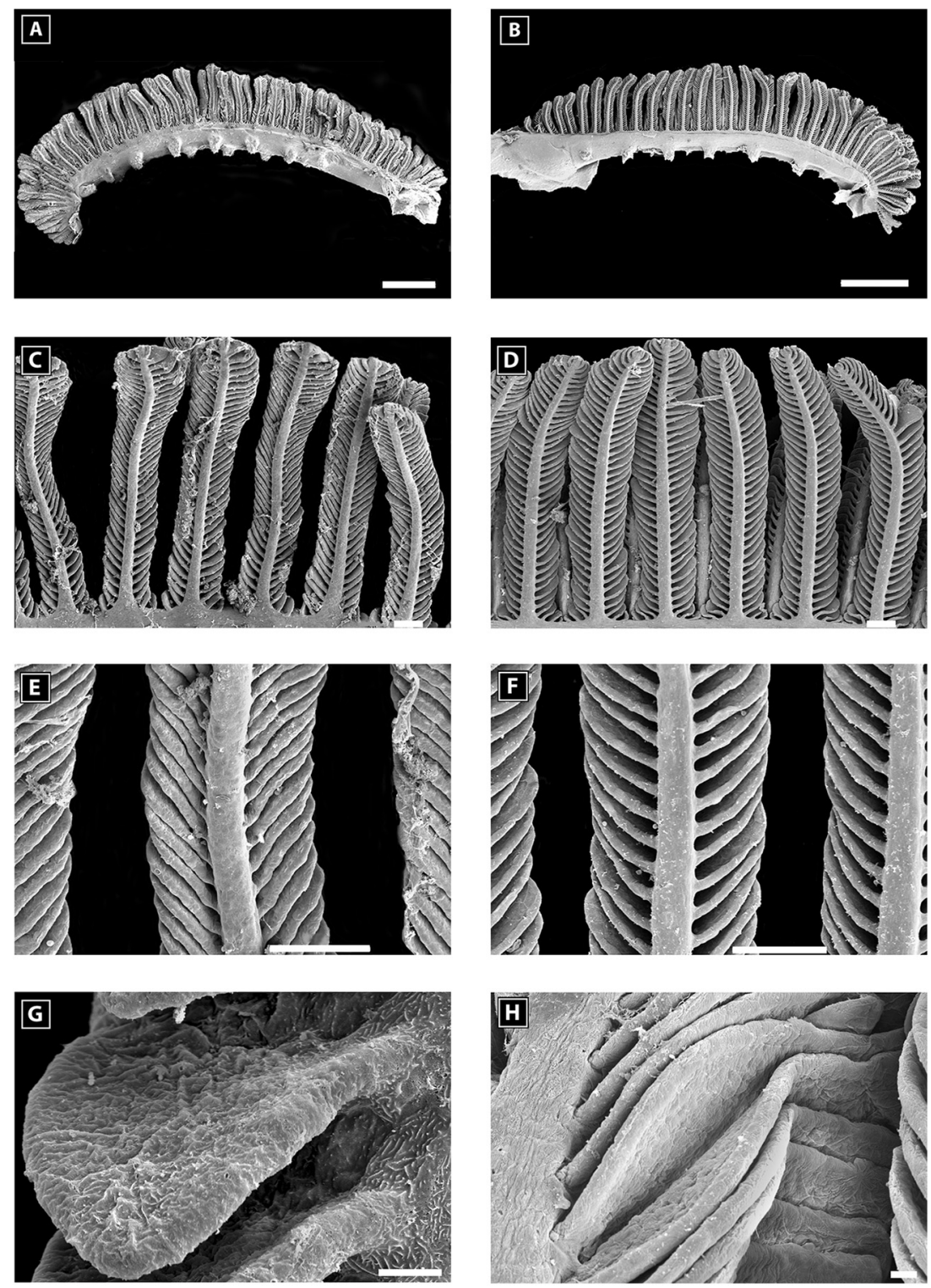

Figure 6. Scanning electron microscopy of a second gill arch of Carapus homei unexposed to holothurians saponin in A, C, E, G and exposed to holothurian saponins in B, D, F, and H. (A) and (B) general views of the second gill arch; (C) and (D) views of the primary lamellae; (E) and (F) views of the secondary lamellae; $(\mathrm{G})$ and $(\mathrm{H})$ details of a secondary lamella. Scale bar is $1 \mathrm{~mm}$ in $\mathrm{A}$ and $\mathrm{B} ; 100 \mu \mathrm{m}$ in $\mathrm{C}, \mathrm{D}, \mathrm{E}$, and $\mathrm{F}$; and $20 \mu \mathrm{m}$ in $\mathrm{G}$ and $\mathrm{H}$.

Marmoratoside A, Holothurinoside G, and Arguside C, respectively. The MALDI mass spectrum obtained for the saponins extracted from the water where the Cuvierian tubules of $B$. atra were incubated displayed eight intense peaks that correspond to triterpene saponins (Fig. 4). The eight ions were detected at $\mathrm{m} / \mathrm{z}\left[\mathrm{M}+\mathrm{Na}^{+}\right] 1125,1141,1287,1303,1329$ (new), 1449, 1463 (Holothurinoside H) and 1479 (Holothurinoside I). Six of them were similar to the body wall mass spectrum, but the relative intensities between both spectra were different. The MALDI mass spectrum of the saponin extract obtained from the body wall of Holothuria forskali (not shown) displayed the eight ions that were also detected at the same $\mathrm{m} / \mathrm{z}$ signals for the saponin extract of the Cuvierian tubules of Bohadschia atra, but the relative intensities between both spectra were different.

\section{Histological and ultrastructural characterization of the gills after saponin exposure}

A comparison of the histology of gills of untreated and treated fishes showed that the carapid gills were much less altered than those of the other fishes (Figs. 5, 6, 7). After the 

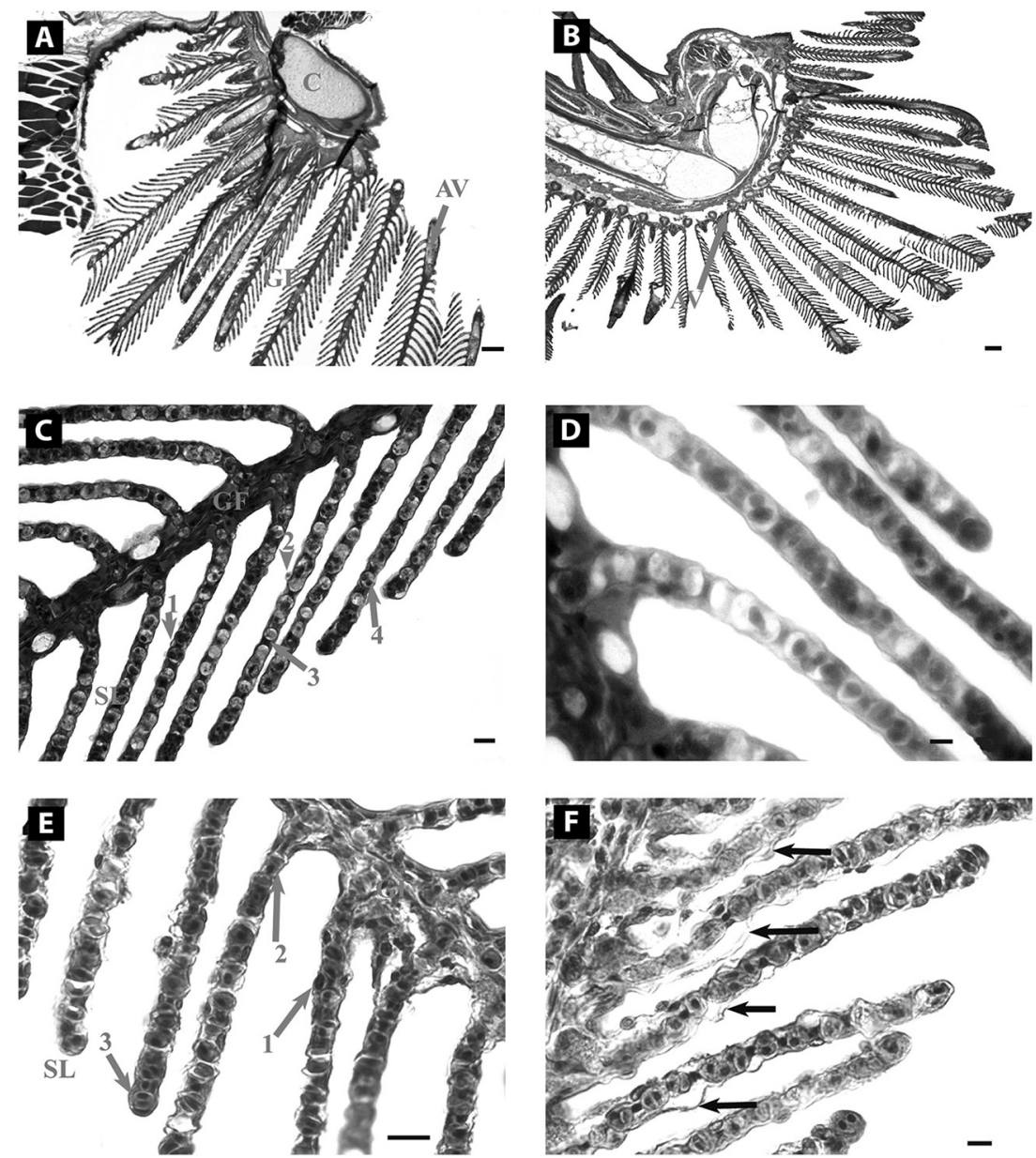

Figure 7. Cross section of a second gill arch and filaments from Carapus acus in A, C, E and from Amphiprion akallopisos in B, D, F; (A) and (B) second gill arch; filaments and secondary lamellae unexposed (C and D) and exposed (E and F) to saponins; AV: afferent vessel; C: central venus sinus; GF: gill filament; SL: secondary lamella; 1: epithelial cell; 2: pillar cell; 3: red blood cell. Scale bar is $100 \mu \mathrm{m}$ in A and B; $50 \mu \mathrm{m}$ in C and D; $10 \mu \mathrm{m}$ in $\mathrm{E}$ and $\mathrm{F}$. Black arrows indicate epithelial alterations.

exposure to saponins, the gills of Amphiprion akallopisos were damaged mostly at the surface of the secondary lamellae (Fig. 5B, D, F, H). Most of the gill filaments were curled and bent. The secondary lamella were swollen, and the space between them was reduced (Fig. 5D). Red blood cells were often observed outside blood vessels, indicating vascular disruption (Fig. 5H). In contrast, the surface of carapid gills did not appear to be affected by exposure to saponins (Fig. 6A to H; Fig. 7).

Histology and TEM observations revealed three cell types in the epithelium of secondary lamellae of $C$. mourlani, E. gracilis, and A. akallopisos: epithelial cells (Figs. 8A, 9B), pillar cells (Figs. 8B, 9A, B), and red blood cells (Fig. 8A to C). Epithelial cells are flat cells about $2 \mu \mathrm{m}$ thick in the middle part, which includes a flattened nucleus (Figs. 7, 9A). The epidermis of secondary lamellae is underlined by a thick basal lamina of $500 \mathrm{~nm}$ (Figs. 8A to C, 9C). The epidermis covers pillar cells and red blood cells
(Figs. 7, 8A, 9A, B). A pillar cell is an I-shaped cell with a central core running from one side of the lamella to the other (Figs. 7, 8B, 9A, B). The shape of pillar cells creates cavities that form the blood vessels (Figs. 7, 8A to C, 9B). A longitudinal section through a secondary lamella shows 13 (in A. akallopisos) to 16 (in the carapid species) blood vessels flanked by the core of the pillar cells (Fig. 7). The thickness of lamella (i.e., the length of pillar cells) is about $6 \mu \mathrm{m}$.

When exposed to saponins, ultrastructural changes were seen in all fish species. In the carapids, small bulges appeared on the surface of the epithelial cells (Fig. 9B, C) and parts of the epithelia appeared contracted (Fig. 9A). In many places, epithelial cells were detached from the basal lamina (Fig. 9B), and many vacuoles also appeared in the cytoplasm of the epithelial and pillar cells (Figs. $8 \mathrm{~B}, 9 \mathrm{~B}, 9 \mathrm{C})$. The red blood cells of the carapids did not appear to be affected by exposure to saponins (Figs. 8A, 

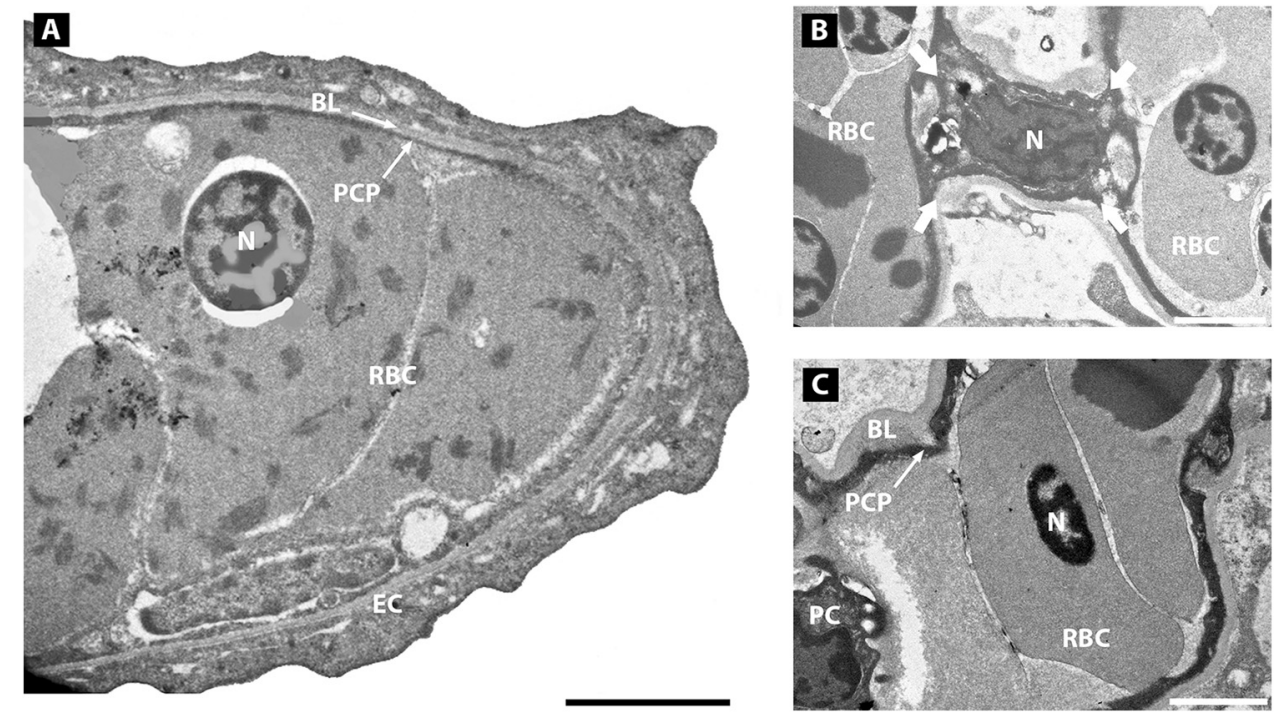

Figure 8. Transmission electron microscopy of a secondary lamella of Encheliophis gracilis unexposed to saponins, showing the tip of the lamella with red blood cells inside vessels and the external epithelium (A), the pillar cells with the departure of the pillar cell processes forming the wall of the blood vessels (B) and red blood cells with details of the vessel wall. BL: basal lamina; EC: epithelial cell; N: nucleus; PC: pillar cell; PCP: pillar cell process; RBC: red blood cell. Scale bar is $2 \mu \mathrm{m}$.

C, 9B). The disturbances in A. akallopisos were always more severe: the TEM observations showed a total disorganization of the tissues with the disintegration of the epithelial cells, pillar cells, and red blood cells (Fig. 9D). Epithelial cells completely disappeared in many places, and multivesicular structures were present instead of the core of pillar cells (Fig. 9D, F). The red blood cells were also damaged and had electron-dense cytoplasm and pycnotic nuclei (Fig. 9E).

\section{Discussion}

Here it has been observed that holothuroid Cuvierian tubules and saponins extracted from the integument of $\mathrm{Bo}$ hadschia atra and Holothuria forskali are lethal for freeliving fishes under experimental conditions. It has also been demonstrated that carapids are much less sensitive to $\mathrm{Cu}-$ vierian tubules as they die later than free-living fishes, and they do not seem to be harmed by the saponins of the holothuroid integument. Mass spectrometry showed that there were three cocktails made of nine (body wall of $B$. atra) or eight saponins (body wall of $H$. forskali and water with $B$. atra Cuvierian tubules) with six saponins in common for the three extracts. The high toxicity showed by Cuvierian tubules does not, therefore, seem to be explained by the qualitative nature of the molecules in the cocktails. Rather, it may be due to the higher concentration of saponins present in the Cuvierian tubules, as shown by Van Dyck et al. (2011).
Parmentier and Vandewalle (2005) were the first to test carapid resistance to the presence of Cuvierian tubules. They placed Cuvierian tubules of three individuals of $B$. argus with the pearlfishes $C$. home $i$ and $C$. boraborensis and some tropical fishes used as controls, in one aquarium. They observed the death of all the fishes after less than $5 \mathrm{~min}$, except for the carapids, which resisted up to 160 minutes (Parmentier and Vandewalle, 2005). The experiments detailed here show similar results. The less resistant pearlfish was $C$. mourlani, which is mainly found in association with asteroids and less so with holothuroids (Parmentier, 2003). Sea stars also possess saponins, but they differ structurally from holothuroid saponins.

Histology and ultrastructure analyses showed that saponins had a negative effect on the secondary lamellae of fish gills, where they caused the detachment of the epithelia, edema and pore formation at the level of the epithelial cells and pillar cells leading to their destruction. In the laboratory, this sequence of events happened quickly in the freeliving fish species and very slowly in carapids. In situ, predatory fishes that approach holothuroids are surrounded by saponins, which are constantly secreted (VanDyck et al., 2011). If these predators disturb the holothuroids, the latter emit higher concentrations and specific saponin congeners into the water (Van Dyck et al., 2011). Moreover, several species also expel some of their Cuvierian tubules through the cloacum, increasing the concentration of saponins in the surrounding water. If predators are still interested in eating the holothuroids, the latter can orientate their bodies to 

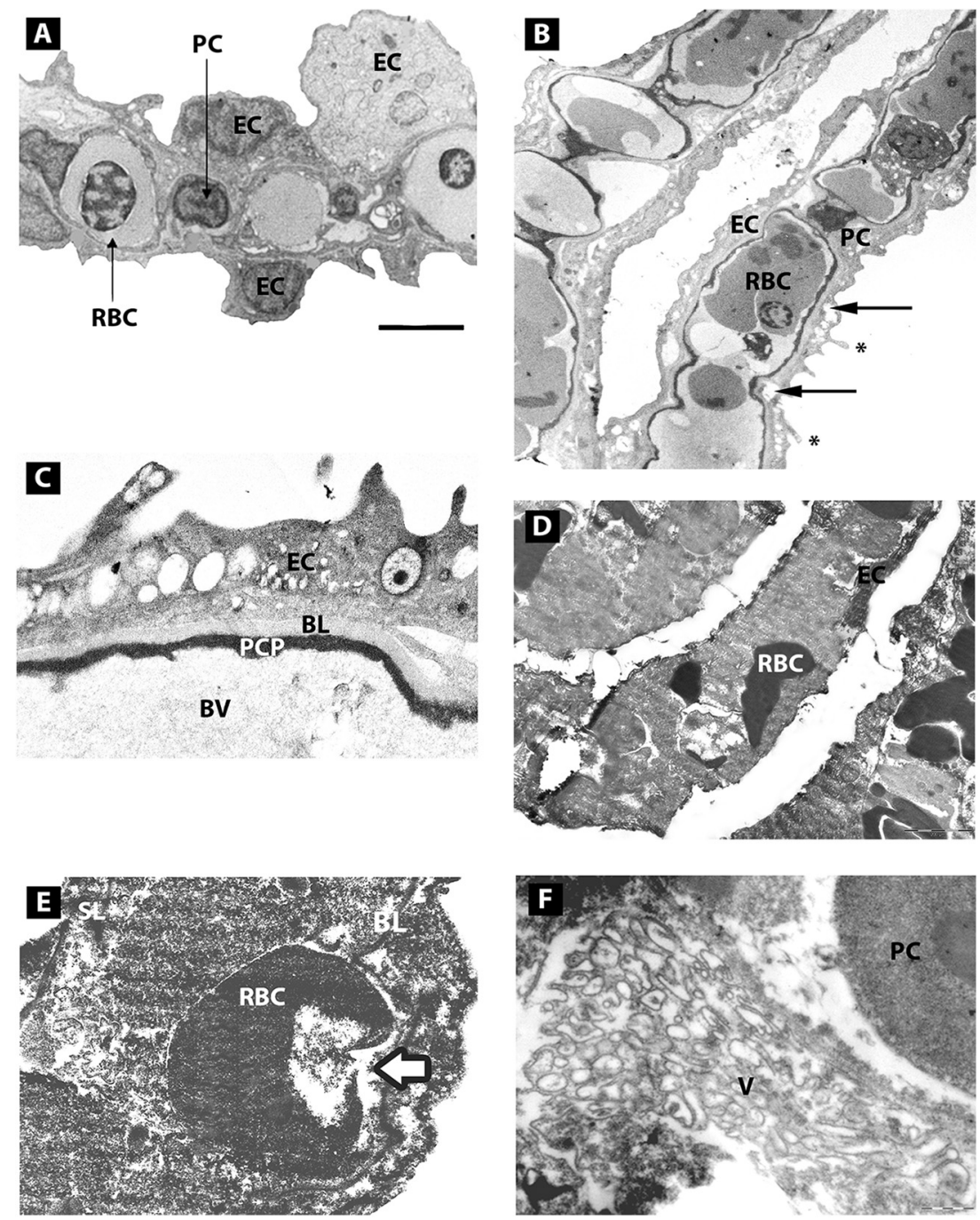

Figure 9. Transmission electron microscopy of secondary lamellae after saponin exposure. Detailed views of secondary lamellae of Carapus acus (A) and C. mourlani (B); details of the vacuoles of epithelial cells, basal membrane and blood vessel outline of C. mourlani (C); details of the alterations in Amphiprion akallopisos showing the destructuration of a secondary lamella (D), red blood cell pycnosis in A. akallopisos (E) and vacuolization in pillar cell in A. akallopisos (F). BL: basal lamina; BV: blood vessel; EC: epithelial cell; PC: pillar cell; PCP: pillar cell process; RBC: red blood cell; SL, saponin-attacking lamina; V: vacuole. Scale bar is $10 \mu \mathrm{m}$ in A and B; $5 \mu \mathrm{m}$ in C, D, E, F and G; and $1 \mu \mathrm{m}$ in H. Arrows and asterisks on part B indicate the forming vacuoles and the deformities on the surface of epithelial cells.

release more Cuvierian tubules in which the predators could finally become stuck. These predators are then in close contact with saponins, which should be enough to repel most of them. Oddly, carapids penetrate the cloacum of holothuroids and place themselves in the respiratory trees without provoking the expulsion of Cuvierian tubules (Parmentier and Vandewalle, 2005). In the laboratory, carapids were unaffected by the glue of the tubules and swam between them without getting stuck. Indeed, most of the saponin content would be conserved inside Cuvierian tubules because they are not expelled outside the holothurian. It was observed that, while carapids are less sensitive to saponins than other fishes, they are affected by high saponin concentrations and, as they are permanently in contact with holothuroids, they must have particular, efficient adaptations to protect themselves.

Parmentier and Vandewalle (2005) suggested that a mechanism occurs at the level of the gills of carapids to explain their high resistance to saponins. Trott (1970) observed an increase in mucus production by Encheliophis vermicularis in response to extracts of Cuvierian tubules. The present results show that the structure of secondary lamellae in carapids is similar to that of other fishes: they are of similar length and thickness, possess a similar number 
of blood vessels, and are made of similar cells (epithelial cells, pillar cells, and red blood cells). As the gill structure does not explain the resistance of carapids to saponins, three other hypotheses can be suggested: (i) the quantity of mucus secreted in carapids is higher than in other fishes, and the thickness of the mucus creates a natural barrier against the toxin, (ii) the nature of the mucus in carapids is different from that of other fishes and includes some molecules, such as enzymes, that can act on saponins and suppress their noxious effects, and (iii) saponins cannot act on carapid gills because the cytoplasmic membrane of their epithelial cells possesses special sterols, as is the case for their hosts. Indeed, the cell membranes of holothuroids are resistant to their own saponins (Stonik et al.,1999). This resistance was proved to be related to the low content of free sterols in membranes of sea cucumbers, to the presence of $\Delta^{7}$ and $\Delta^{9(11)}$-sterols as well as sulfated and glycosylated sterol conjugates instead of $\Delta^{5}$-sterols (Popov et al., 1983 ; Stonik and Elyakov, 1988). $\Delta^{5}$-sterols are the main site of action of saponins (Mackie,1976). It is therefore possible that the composition of carapid cell membrane is similar to that of their echinoderm hosts and that carapids possess a lot more $\Delta^{7}$ or $\Delta^{9(11)}$-sterols than $\Delta^{5}$-sterols. This already explains why echinoderms are unaffected by high levels of saponins in their tissues, and why exposure to saponin solutions, lethal to all other fishes, would be without effect on Carapidae. Further experiments should investigate these three hypotheses to highlight the mechanism that results in carapids being unaffected by host saponins.

\section{Acknowledgments}

The authors thank the IH.SM (Toliara, Madagascar) for having allowed them to carry out their experiments within their institute and the Madagascar Holothurie team for helping to obtain C. mourlani, E. gracilis, E. vermiops, and the free-living fish species. Thanks also go to the STARESO team (Calvi, France) for helping to obtain C. acus, to S. Planes (CRIOBE, Moorea, French Polynesia) for helping to obtain C. boraborensis and C. homei, and to M. Todesco for technical assistance. This work was supported by a FRFC project (FNRS, Fonds National de la Recherche Scientifique). This study is a contribution by the Centre Interuniversitaire de Biologie Marine (CIBIM).

\section{Literature Cited}

Bakus, G. J. 1973. The biology and ecology of tropical holothurians. Pp. 325-367 in Biology and Geology of Coral Reefs 2, A. O. Jones and R. Endean, eds. Academic Press, London.

Bordbar, S., F. Anwar, and N. Saari. 2011. High-value components and bioactives from sea cucumbers for functional foods-a review. Mar. Drugs 9: 1761-1805.

Caulier, G., P. Flammang, P. Gerbaux, and I. Eeckhaut. 2013a. When a repellent becomes an attractant: harmful saponins are kairomones attracting the symbiotic harlequin crab. Sci. Rep. 3: 1-5.
Caulier, G., P. Flammang, P. Rakotorisoa, P. Gerbaux, M. Demeyer, and I. Eeckhaut. 2013b. Preservation of the bioactive saponins of Holothuria scabra through the processing of trepang. Cah. Biol. Mar. 54: 685-690.

Cleveland, A., E. A. Verde, and R. W. Lee. 2011. Nutritional exchange in a tropical tripartite symbiosis: direct evidence for the transfer of nutrients from anemonefish to host anemone and zooxanthellae. Mar. Biol. 158: 589-602.

Demeyer, M., J. De Winter, G. Caulier, I. Eeckhaut, P. Flammang, and P. Gerbaux. 2014. Molecular diversity and body distribution of saponins in the sea star Asterias rubens by mass spectrometry. Comp. Biochem. Physiol. B 168: 1-11.

Dietrich, H., and A. Fontaine. 1975. A decalcification method for ultrastructure of echinoderm tissues. Biotech. Histochem. 50: 351-354.

Elliott, J. K., and R. N. Mariscal. 1997. Ontogenetic and interspecific variation in the protection of anemonefishes from sea anemones. J. Exp. Mar. Biol. Ecol. 208: 57-72.

Elyakov, G., V. Stonik, E. Levina, V. Slanke, T. Kuznetsova, and V. Levin. 1973. Glycosides of marine invertebrates. II. A comparative study of the glycoside fractions of Pacific sea cucumbers. Comp. Biochem. Physiol. B 44: 325-336.

Flammang, P., J. Ribesse, and M. Jangoux. 2002. Biomechanics of adhesion in sea cucumber Cuvierian tubules (Echinodermata, Holothuroidea). Integr. Comp. Biol. 42: 1107-1115.

Ganter, P., and G. Jollés. 1969-1970. Histochimie Normale et Pathologique. Gauthier-Villars, Paris.

Guo, M., F. Song, Z. Liu, and S. Liu. 2006. Characterization of triterpenoidic saponin mixture in crude extracts from leaves of Acanthopanax senticosus harms by saponin structural correlation and mass spectrometry. Anal. Chim. Acta 557: 198-203.

Hamel, J. F., and A. Mercier. 2000. Cuvierian tubules in tropical holothurians: usefulness and efficiency as a defence mechanism. Mar. Freshw. Behav. Physiol. 33: 115-139.

Kalinin, V. I., M. Anisimov, N. Prokofieva, S. Avilov, S. Afiyatullov, and V. Stonik. 1996a. Biological activities and biological role of triterpene glycosides from holothuroids (Echinodermata). Pp. 139-181 in Echinoderm Studies 5, M. J. Jangoux, ed. CRC Press, Boca Raton, FL.

Kalinin, V. I., N. Prokofieva, G. Likhatskaya, E. Schentsova, I. Agafonova, S. Avilov, and O. Drozdova. 1996b. Hemolytic activities of triterpene glycosides from the holothurian order Dendrochirotida: some trends in the evolution of this group of toxins. Toxicon 34: 475-483.

Kalinin, V. I., D. L. Aminin, S. A. Avilov, A. S. Silchenko, and V. A. Stonik. 2008. Triterpene glycosides from sea cucucmbers (holothurioidea, echinodermata). Biological activities and functions. Stud. Nat. Prod. Chem. 35: 135-196.

Kitagawa, I., and M. Kobayashi. 1977. On the structure of the major saponin from the starfish Acanthaster planci. Tetrahedron Lett. 18: $859-862$.

Kubanek, J., J. R. Pawlik, T. M. Eve, and W. Fenical. 2000. Triterpene glycosides defend the Caribbean reef sponge Erylus formosus from predatory fishes. Mar. Ecol. Prog. Ser. 207: 69-77.

Li, R., Y. Zhou, Z. Wu, and L. Ding. 2006. ESI-QqTOF-MS/MS and APCI-IT-MS/MS analysis of steroid saponins from the rhizomes of Dioscorea panthaica. J. Mass Spectrom. 41: 1-22.

Mackie, A. M., and A. Turner. 1970. Partial characterization of a biologically active steroid glycoside isolated from the starfish Marthasterias glacialis. Biochem. J. 117: 543-550.

Mackie, G. O. 1976. Propagated spikes and secretion in a coelenterate glandular epithelium. J. Gen. Physiol. 68: 313-325.

Markle, D. F., and J. E. Olney. 1990. Systematics of the pearlfish (Pisces: Carapidae). Bull. Mar. Sci. 47: 269-410.

Matsuno, T., and J. Iba. 1966. Studies on the saponins of the sea cucumber. Yakugaku Zasshi 86: 637. 
Mebs, D. 1994. Anemonefish symbiosis: vulnerability and resistance of fish to the toxin of the sea anemone. Toxicon 32: 1059-1068.

Nigrelli, R. 1952. The effects of holothurin on fish, and mice with sarcoma 180. Zoologica NY 37: 89-90.

Parmentier, E. 2003. Contribution to the study of the relations between fish of the family of Carapidae and their invertebrate hosts: a multidisciplinary approach. Ph.D. thesis, University of Liege, Belgium. 316 pp.

Parmentier, E., and K. Das. 2004. Commensal vs. parasitic relationship between Carapini fish and their hosts: some further insight through $\delta^{13} \mathrm{C}$ and $\delta^{15} \mathrm{~N}$ measurements. J. Exp. Mar. Biol. Ecol. 310: 47-58.

Parmentier, E., and L. Michel. 2013. Boundary lines in symbiosis forms. Symbiosis 60: 1-5.

Parmentier, E., and P. Vandewalle. 2003. Morphological adaptations of pearlfish (Carapidae) to their various habitats. Pp. 259-274 in Fish Adaptations, A. L. Val and B. G. Kapoor, eds. Science Publishers, Enfield, NH.

Parmentier, E., and P. Vandewalle. 2005. Further insight on carapidholothuroid relationships. Mar. Biol. 146: 455-465.

Plasman, V., J. C. Braekman, D. Daloze, M. Luhmer, D. Windsor, and J. Pasteels. 2000a. Triterpene saponins in the defensive secretion of a chrysomelid beetle, Platyphora ligata. J. Nat. Prod. 63: 646-649.

Plasman, V., J. C. Braekman, D. Daloze, D. Windsor, and J. Pasteels. 2000b. Triterpene saponins, quaternary ammonium compounds, phosphatidyl cholines, and amino acids in the pronotal and elytral secretions of Platyphora opima and Desmogramma subtropica. J. Nat. Prod. 63: 1261-1264.

Popov, A., N. Kalinovskaia, T. Kuznetsova, I. Agafonova, and M. Anisimov. 1983. Role of sterols in the membranotropic activity of triterpene glycosides. Antibiotiki 28: 656-659.

Prokof'eva, N. G., E. L. Chaikina, A. A. Kicha, and N. V. Ivanchina. 2003. Biological activities of steroid glycosides from starfish. Comp. Biochem. Physiol. B 134: 695-701.
Segal, R., and E. Schlösser. 1975. Role of glycosidases in the membranlytic, antifungal action of saponins. Arch. Microbiol. 104: 147150.

Stonik, V., and G. Elyakov. 1988. Secondary metabolites from echinoderms as chemotaxonomic markers. Pp. 43-86 in Bioorganic Marine Chemistry, P. G. Scheuer, ed. Springer, Berlin.

Stonik, V., V. Kalinin, and S. Avilov. 1999. Toxins from sea cucumbers (holothuroids): chemical structures, properties, taxonomic distribution, biosynthesis and evolution. J. Nat. Toxins 8: 235-248.

Thompson, J., R. Walker, and D. Faulkner. 1985. Screening and bioassays for biologically-active substances from forty marine sponge species from San Diego, California, USA. Mar. Biol. 88: 11-21.

Trott, L. B. 1970. Contributions to the Biology of Carapid Fishes (Paracanthopterygii: Gadiformes). University of California Press, Oakland.

Trott, L. B. 1981. A general review of the pearlfishes (Pisces, Carapidae). Bull. Mar. Sci. 31: 623-629.

Van Dyck, S., G. Caulier, M. Todesco, P. Gerbaux, I. Fournier, M. Wisztorski, and P. Flammang. 2011. The triterpene glycosides of Holothuria forskali: usefulness and efficiency as a chemical defense mechanism against predatory fish. J. Exp. Biol. 214: 1347-1356.

Van Dyck, S., P. Flammang, C. Meriaux, D. Bonnel, M. Salzet, I. Fournier, and M. Wisztorski. 2010. Localization of secondary metabolites in marine invertebrates: contribution of MALDI MSI for the study of saponins in Cuvierian tubules of H. forskali. PLoS One 5: e13923.

Van Dyck, S., P. Gerbaux, and P. Flammang. 2009. Elucidation of molecular diversity and body distribution of saponins in the sea cucumber Holothuria forskali (Echinodermata) by mass spectrometry. Comp. Biochem. Physiol. B 152: 124-134.

Yamanouchi, T. 1955. On the poisonous substance contained in holothurians. Publ. Seto Mar. Biol. Lab. 4: 183-203. 